\title{
Narratability of Knowing and Being: The Ontic Role of Materia Poetica in the Post-Mechanical Age
}

\author{
Milan Jaros ${ }^{1}$ \\ ${ }^{1}$ Milan Jaros, Newcastle University, UK \\ Correspondence: Milan Jaros, Newcastle University, Newcastle upon Tyne, NE1 7RU, United Kingdom.
}

Received: June 6, 2020

Accepted: July 15, 2020

Online Published: July 29, 2020

doi:10.20849/jed.v4i2.778

URL: https://doi.org/10.20849/jed.v4i2.778

\begin{abstract}
The realm of mystery of matter that has long inspired creative minds has been broken by runaway complexification of life into fragments tossed around in voids of 'total presence'. Apart from notable exceptions, the origin and actuality of the material condition of humans remain hidden from view by layers of 'neo-baroque' allegories framing narratives of the post-mechanical age. It is argued that resurrection of the ontic role of encounters with material reality may restore what has always served as an indispensable source of personal identity and life-sustaining narratives. It is also a means to fostering narrative novelty in the process of instilling timely attitudes and competences, with a view to ensuring that every individual can effectively engage with materiality of their presence and build upon its appreciation and on any inspiration it can offer, at the pace and level of accomplishment matching their personal ability and circumstances. It is this grounding of knowing and being that offers the promise of a bottom up transition to citizenship in a shared Common in which the key measure of value rests with promoting personal independence and social emancipation! What are the key stages of 'allegorisation' of narrativity and literary narratives in particular leading to the meta-modern present? What is the fate of materia poetica? The model of curriculum and competence development - grounded in object based, project driven, personal ownership of knowing, and amplifying the tutor-learner component at the expense of top down 'talk and chalk' - recently developed to take higher education into the digital age may be instrumental in delivering such objectives, and prove to be particularly relevant post-Covid 19.
\end{abstract}

Keywords: corporeality in literary narratives, allegory, competence and curriculum development, human systems and emergent knowledge

\section{An Overview}

Already in his Reveries of a Solitary Walker, Jean Jacques Rousseau, reflecting on the fate of the Project of Enlightenment he himself had done much to bring about and promote, lamented about the vocabulary of the Age of Reason. Once the Cartesian mind acquires the confidence needed to read the book of Nature in the language of independent order parameters, who someone is eludes humans. Their language leads them into saying what he is. Much of effort in arts and literature, and in humanities at large has since been increasingly devoted to recovering at least some degree of individual "unique existent" - and never more so than after the "digital enhancement' of what informed Rousseau's laments. We are destined to be wanderers in search of our life-story just like Jean Jacques was. Alas! His project has been over-successful! The social structures have been unable to catch up with the speed of the advance of techno-science, at least in the last hundred years or so. Our journey is no longer grounded in the certainties of Cartesian reason and mimetic perspectival space for which there is no stable, readily accessible replacement. It takes us through the deep forests of invasive, networked communications, and into playing fields masterminded by runaway complexifications! If so, what is it that may serve as a directional inspiration grounded in material reality for story-telling that makes life liveable?

One does not have to read Sigmund Freud or latest products of neuro-science to know that already an infant, as soon as its motor functions begin to catch up with those of its mind, reaches for any object - to touch and throw anything to achieve some degree of separation between the I and the Other without which neurosis takes over. This "catching up" does not end with the "mirror stage" of human development. It rapidly intensifies as we get exposed to more influences and impositions from the world out there. More succinctly, humans in order to be human put before themselves products of their engagements with matter, of work wearing its onto-epistemic hat, so as to duplicate themselves in what is before them, to recognise and perpetually to renew themselves in the 
eyes of others, and in the world of things and events in general. This is a necessary condition not only for learning and knowing but also for being, and for remaining sane. Availability of relevant meaning making, its recordability and retrieval is the other condition. It will be argued that today both these conditions are problematic. Our notion of materiality and its relation to meaning making is challenged by ever increasing numbers of manipulative mediators standing between the I and the other.

The larger question underlying this appraisal of the human condition of today is about the capacity of human beings to respond to the feverish generation of new social and material structures and tools - particularly so as to make people at home in the process of metamorphosing novel work practices into enabling personal ownership of work and life experience as well as social emancipation. The question is not so much about the degree to which what happens in the 'lab and cloister' or on the factory floor is or is not 'adequately' invoked in the story-telling filling the public space, but about what new ways of ordering thought and of shaping the elbow room for free-wheeling intuition and imagination they impose! And what happens when the mystery of matter, of matter in the role of a free agent cleansing and opening the mind, does not come to be seen just in showers of meteorites or crystalline planes of diamond as it has done for millennia? In spite of daily feed of overblown images of medialised consumption whose reality is 'Sci Fi virtuality' of the screen, most perhaps still remember from school days Eve's taking the forbidden fruit, the apple falling on Isaac Newton's head, Johannes Kepler's playing with show flakes, the doodles, plants and toys made immortal by famous poets such as e.g. William Blake, William Wordsworth, William Yeats, Ezra Pound, Oscar Wilde, and Rainer Maria von Rilke, but also by painters, philosophers, and physicists such as Oscar Kokoschka, Walter Benjamin, and Niels Bohr, may be even Marcel Proust's tea spoon and Madeira cake. Today we encounter novelties of form and organisation of all kinds whose actual material structure and order parameters remain hidden from view. This is chiefly because they are by many orders of magnitude removed from the scale of powers of human senses and further obscured by pseudo-structures of surface appearances staring at us everywhere; their materiality and material organisation are transported in our habitual reactions to the void of the virtual, deprived of directionality of reason and valuation, where anything goes. For there they acquire existence in the form of a box whose reality reduces to a few buttons. It is enough to know a few 'consumable parameters', like speed or power, given to us in the language of appearances that never touch the level of the causal forces controlling the how and why of a product or event.

Resurrection of the ontic role of personal encounters with material objects is needed today more than ever as the ultimate source of identity constitutive, onto-epistemic means of legitimation and redemption of life sustaining narratives caught in the complexified matter with a life of its own. It is to instil a timely attitude, acquisition of habitual practices with fitting competences, and self-confidence in applying them. They will be best achieved by grounding them in a personal ownership of experiential situations the way an archaeologist uncovers layer by layer a buried city. The model of curriculum and competence development recently developed to take higher education into the digital age may be instrumental in delivering such objectives and prove to be particularly relevant in post-Covid 19 conditions. It is such engagements with object-ness in living places that are indispensable in the process of un-concealing any part of the "real existent" hidden under layers of appearances characteristic of the "episteme of meta-modernity".

"Allegory" may not be the most popular term in the word market today. When the media refer to a piece telling about one thing under the guise of another - what happens anywhere from pop stars riding fancy horses on the screen supposed to be selling cars to programmatic 'trifling' with history by politicians and novelists alike - they might choose words like "spin" or rich products of the vocabulary of "political correctness", "economy with truth", "deep-fakes", etc. However, invoking a term like allegory with its weighty aura in cultural history brings back the memory of our cultural development - and indispensability of such memory - in order to facilitate comparisons revealing the way telling one thing by means of another has changed in time, i.e. to make use of it as a variable for constructing genealogy of communication as a function of social development. Today's quantitative empirical methods and tools make it possible to raise the level of our accomplishments in making and modelling patterns of matter whether they fall into domains of science or arts, and cast them as it were for posterity into genealogical sequences organized according to the level of complexity of the relevant sets of independent parameters constituting retrievable, transparently independent records for anyone to examine and to update. It is an outstanding intellectual and particularly educational challenge to create means for achieving habitual attitudes and competence enabling every citizen as early in their life as possible to bridge the growing gap between cause and effect, for-itself and for-others that threaten to plague decision making that are crucial for our individual and collective wellbeing. 


\section{Background Notes}

The upheavals in the $16^{\text {th }}$ and $17^{\text {th }}$ Europe that followed collapse of the authority of Summa Theologica, and decline of the Renaissance canon led to what we have become used to calling the Baroque. Then history is a series of calamities bringing rupture and insecurity. After the breakdown of what was perceived to be a universal model of the world upheld by the belief in continuity of all-encompassing social structures, the thinker deprived of a stable source of meaning resorted to allegory. For the early forms of representation, religious and secular, all drew in their own peculiar way credibility and effectiveness from reference to the absolute and eternal enshrined in symbols, signs, narratives, and objects generally accepted as recalling and typifying an idea or quality and standing for an established tradition. In the $16^{\text {th }}$ century the term allegory gradually lost its old meaning as reference to "ancient value" and came to stand for a work in which a deeper meaning underlies the literal or superficial meaning - i.e. speaking of one thing under the guise of another. This was a kind of 'representation of representation' fit for the dangerous and chaotic social conditions of the baroque era. For the basic characteristic of allegory is openness to multiplicity of meaning. In contrast to the Greek legacy of totality of perfection in things and thought, allegory shatters its object and unhinges any meaning. In the chaotic space of the warring Europe the whole had become too contingent, unpredictable, and problematic to hold on to. What remained was the capacity to focus on a detail linked to the whole only by the weakest of strings, on a lone fragment. The old saying that God (or Evil) is in the detail still applied but with a grin of huge irony. For it was the 'detail' as a feature of and inseparable from the grasp of the Whole that has always played a key part in any major advance of our civilisation. The tiny deviation of data from perfect circular orbit that had always been known and taken for a measure of error in observations not only turned star gazing into science but shattered assumptions on which stood most dogmas of the Ancient Regime. It was when Johannes Kepler realised that Tycho de Brahe's instruments - almost certainly for the first time - offered a testable measure of error. Kepler - the Imperial and Royal Mathematicus - went on to prove that the planetary orbits were elliptic and opened the way for Newton's intervention that legitimated the coming of the age of reason exercised by an independent observer.

As the crisis of the neo-liberal regime grew in the course of recent decades, the most visible expression of rising instability again turned out to take the form of montage and pastiche, of the accidental, singular and spectacular whose origin lies in the $16^{\text {th }}$ and $17^{\text {th }}$ century baroque. The post WWII society, deprived of divine certainties of speculative reason mortified in gas chambers, murderous battlefields, and politbureaus together with whatever was left after 1918 of Kantian faith in transcendental philosophy and its off-spring Utopias, functions under perpetual thread of catastrophic discontinuities kept largely as if in the 'background' by senseless escapism and consumption. However, the product of recasting modernist ontology into the current regime of 'neo-baroque' happens to be quite unlike its $17^{\text {th }}$ century pre-cursor. It is dominated by the flow of objectified material exchanges driven almost undisturbed by medialised networks programmed to self-promotion irrespective of social consequences. The wisdom of Karl Marx's "All that is solid melts into air" has found a higher degree of complexity in the coming of "digitally enhanced serfdom" maintained by invisible puppeteers. Perhaps, as wittily expressed by Walter Benjamin, around the middle of the $20^{\text {th }}$ century history moved towards becoming merely an account of a process of "translations"? What was left of the Kantian autonomous subjects and objects was their narratability drawing on fragments linked to the past at best by pseudo-structures of "citability". In this picture, history of artefacts becomes inseparable from human history whatever that may be. Is the task of philosophy, as Benjamin suggested, merely "to establish the becoming of phenomena in their being"? What are the key stages of the process leading to 'allegorisation' of human expression peculiar to the digital age? What constitutes capacity for reading the meaning of order generation hidden behind layers of appearances - and for separation of cause from effect in particular?

\section{Actuality of Allegory}

The conceptual grounding of allegory 'discovered' by the baroque came to be actualised most expressively in new musical and theatrical forms which quickly moved from privileged spaces of the palace and cathedral to streets and squares; genres from opera buffo to Trauerspiel (mourning) plays turned out to be best equipped to get across the general historico-philosophical standpoint in which the relation of humans to the absolute and to continuity of thought and habit ceased to be immanent to life. Unlike the Greek tragedy, baroque plays soon became a quasi-autonomous construct available for instant re-territorialization anywhere. Their allegories devalued the actual material content of persons and emblems, turning them into signposts of an enigmatic process thriving on open-ended arbitrariness of floating in a void. It tolerated, indeed invited 'critique' from any quarter for there was always a space for any such intervention - though without ever being able to hurt directly its 'target'. Baroque narrations and plays no longer pointed directly to a recognisable 'higher' life. They revelled in an infernal game of reflections destined to dethrone anything that looked like illusions of transcendental truths 
always ultimately exposed as believable only by means of 'mirrors and puppets' that feed on conditions of great misery in the world traumatised by spiritual and material wretchedness. This ambiguity and openness to re-interpretation was exploited by both the baronial power of the establishment as well as by those who looked for a way to challenge it without falling victim to persecution awaiting any direct challenge to the system. For allegory lends itself as a powerful tool not only in popular entertainment but particularly in cultural and political struggles. One Risorgimento after another, in Italy, in the Kingdom of Bohemia and elsewhere used puppets and marionettes, and later labyrinthal and uncanny narratives often delivered by travelling performers on improvised stages. Though the message was hidden behind the veil of allegory, the 'crypt' was owned one way or another by those for whom it was intended. The cumulative legacy of many years of just such structuring of human expression in all walks of life became an invaluable depository of social practices from acts of resistance to those of domination and oppression. A notable late product of this process was the Prague phenomenon of Jara Cimrman brought into existence in 1965, in the heady days of rising resentment to the exhausted regime of Soviet satellites, in The Spider (an old Prague wine cellar). There was a French model in the (real) person of Jacques Carelman - a post-Dadaist inventor and poet known from many of his exhibitions and lectures and immortalised by the well-known film director Rene Clair in his essay introducing Carelman's 'retrospective' exhibition in Musee des Arts Decoratifs in Paris in 1972. However, unlike Carelman, Jara Cimrman was born as a wine cellar simulacrum. The event was well in keeping with the Czech literary tradition deeply steeped in centuries of resistance to Austrian oppression and systematic destruction of the Czech language going back to the dark decades of religious wars of the $17^{\text {th }}$ century, to tales of Prague's Golem and Faustus, to the trickster and Mephistophelean figures of popular stories drawing on well known fairy tales. They were presented and re-presented not only in places frequented by patriotic elites but also in 3000 or so registered marionette theatres flourishing well into the $20^{\text {th }}$ century in what is now Czech Republic. This process was made known outside its place of origin by writers like Alois Jirasek, but also by Franz Kafka's K. and Jaroslav Hashek's Good Soldier Schweik, and more recently by heroes of a peculiarly Czech version of political theatre and novel created by Bohumil Hrabal, Vaclav Havel, Milan Kundera and others during the last decades of the communist party rule. Cimrman's plays, his opera, his 'memorabilia' found a permanent home, right at the bottom of what is a miniature version of the Eiffel tower. It sits at the top of the highest hill in Prague offering a spectacular view of the city. There you could see him photographed with 'his' family, his admirers, his fellow inventors, writers and politicians, and, significantly, see and touch his inventions. They are 'real' objects, of authentic material and appearance and in a quasi-functional condition, material exhibits e.g. of a fireman's bicycle, an air pump, models of airplanes, musical instruments, and many other artefacts all of quite real size and body yet belonging in the spirit of gaming allegories to the kingdom of papa Ubu's pata-physics; the planes do not quite fly and the pump does not quite pump!

\section{4. "Digitally Enhanced" Aesthetisation of the Material Condition of Humans}

The tradition of universalistic manner of handling conceptualisation as well as narratability of life prevailed in the arts and sciences alike - be it with the help of elaborate linguistic gymnastics - almost to the end of the long $19^{\text {th }}$ century. However, with advancing modernity the conditions perceived as legitimating this outlook became unsupportable even for some of its ardent advocates. The $20^{\text {st }}$ century brand of fragmentation and contingency of being and doing, and the misery of rising inequality and insecurity reminiscent of that which fostered the rise of baroque allegory was brought to new heights by 'digital enhancement'. Extremes of wretchedness and senseless waste have been wired into work practices maintained by norms of runaway complexification. In place of the Traeurspiel plays and opera buffo there appeared pastiche-like modes of performance peculiar to cultural capitalism of "total presence". Addressing substantial change in new plays and narratives with forward looking directionality of content and form has been sidelined into the realm of fringe activity starved of resources and legitimity. Instead, hidden behind the veil of recognisability provided by dubious references to famous authors, e.g. "after Chekhov", well known narratives are ruthlessly recast to serve political ends and financial gains of this or that sect of the neo-liberal regime. They all find history proper 'inconvenient'. The image of timelessness of desire for spectacle and consumption in the void of libertarian no-man-land-ness is indispensable for maintaining control of the playing field today. This de facto condemns coming generations to life without past and consequently also without future! Any objective possibility of fulfilment of directional thought and its aims no matter how well intended vanishes in the digitally mastered black hole of trifling with truth. And whatever possible social benefit may still remain in its effectiveness, today's attempts to say by other means what cannot for whatever reason be said directly is doomed to failure because of the absence of a commonly shared crypt such those that fostered e.g. the Italian and Czech Risorgimento. The underlying narrative patterns of such allegories contain insatiable will to meaning and salvation without ever providing it. Since the realm of objects has been mortified by the allegorist's desire to throw a deceptive cloak over the place and time of the narrative 
scenario, they can only maintain the appearance of such a promise and its dramatic tension by perpetually re-casting the framing of allegory, by deferring its promise ad infinitum. Hence any violence, tyranny, and their obscenities are rendered 'mute' making the hysteria of their marketing 'natural'. In the open space of the neo-baroque allegory, the good and evil reveal themselves as something subjective. Yet they are there, to be read in terms of a meaning given by some ephemeral crypt.

\section{Genealogy of Neo-Baroque Allegories}

Aesthetisation of material exchanges and of their empirical social content created a huge open space charged with compulsion to de-problematise materiality by employing new forms of performance designed perpetually to re-territorialise and re-contextualise it to suit the occasion. Hence the 'baroque' fancy in what has only recently belonged to the realm of ignorable singularities, oddities, and imperfections unworthy of sharing the symbolism of modernist notion of perfection. The triumph of this pseudo-subjectivity is that it is acted out in a cathedral of void in perpetual motion. In a well delivered spectacle, it has an effect similar to the promise of salvation offered by its baroque precursor!

What then are the constitutive stages of 'allegorisation' of human expression from the late modern to meta-modern present? In the course of the long $19^{\text {th }}$ century, modernity side-lined the concept of Cartesian perspectival space and its mimetic "renaissance cone" fostered by one to one relation between extension and object-ness. This process was rendered obsolete by the advent of Einsteinian picture of the Universe that ultimately delegitimised the traditional sources of ontic and epistemic stability on which both the arts and sciences depended. Already artists of the avant-garde braved a radical departure from the mimetic mode by indulging in programmatic 'distortions' of the visible. Paul Cezanne spent hours sitting in front of his models and landscapes - to "render visible" the way things in space and time are "peopled"! Their claim to immortality was laid down in manifestos couched in the language of subjectivism and individualisation of experience. And then, in their more mature stage of development, masters of this project like Wassily Kandinsky and Pablo Picasso tacitly or openly declared their contribution to be a continuation of the past artistic endeavour, again claiming its relation to the absolute as a measure of the work's worth! But in place of moments of eternity accredited by a divine gift of revelation and its masterly uptake of tradition, the claim to immortality reappeared in the shape of new forms of man-made order and ordered structuring determining taxonomy of their masterpieces or "isms" preserved as it were for posterity by what was purported to be different forms of spatial organisation. In the first decades of the $20^{\text {th }}$ century, the metric was quite visible, e.g. in the shape of Picasso's triangles, well recognisable pieces of human bodies, or the checkerboard structure of Paul Klee's compositions. Indeed, already the impressionists opened this gambit by making their brand - of what after Charles Baudelaire's brilliant intervention became known as the first "ism" - recognisable by its very transparent 'metric' of representing the visible: by the 'lens of Newton', i.e. in units of well-defined marks on the canvas in primary colours.

The decades after WWII inaugurated the advent of man-made materials and systems exceeding by many orders of magnitude and precision anything within the reach of human senses and hands. Though these new forms of order are at the site of their origin well defined by independent parameters with transparent and empirically determined limits of applicability, the structure of causal forces ultimately determining the way the social of our techno-scientific civilisation can and must function is no longer 'visible'. Nor is it easily accessible outside the lab and cloister where it was invented. Indeed, manifestations of such discoveries, anywhere from shapes of cars and phones to the devices that drive them - not to speak of their rapid, indiscriminate uptake by arts and humanities in the quest for novelty - are invariably several times removed from what made them possible. The intermediate layers, dominated by networked communication systems, appear to the uninitiated observer looking for meanings only superficially connected and possess no apparent vectors of directionality.

The potential shock to the socio-cultural realm of new levels of man-made complexity in the material condition of humans was noted by the sharpest of minds already in the 1960ties. They were struck by the coming of collapse of 'closure' characteristic of late modernity as formulated in works of e.g. Clement Greenberg and John Rawls. It led to what is now remembered as post-modernism and associated with names of Jacques Derrida, Paul de Mann, and Michel Foucault - to name just some of the best known founding figures. Their brand of critique was to make sense of the abyss so created by systematically "deconstructing" what soon turned out to be illusions about the original drivers of some of the best known contributions to progress in human self-understanding and its methods. It was then that, for example, we were reminded that Copernicus set out to prove Aristotle right rather than put the first big nail into the coffin of his doctrines. And that Newton spent more time and energy on studies of alchemy and doctrines of Rabbi Maimonides then on his calculus and laws of motions for which he is deservedly famous; furthermore his was a project about celebration of the glory of God's 
creation rather than about advent of dis-interested knowledge we the school children of the 1950ties were taught to admire.

Though Derrida's intervention opened the way for a flood of such deconstructions, just as the post-modernist project was about to pass its summit in the early 1990ties, the world was plunged into a potent mix of networked, globalised knowledge and production, of communication systems beefed up by ever increasing levels of complexity that finally destroyed any prospect of generally accessible, "narratable" link between causes and effects. Such a link, which is always a necessary condition for reaching a relevant explanation, became rarely achievable even by highly educated and skilled people. The very possibility of its existence departed from most agendas of accelerated action spaces in which the timing of one's intervention and choice of its presentation were at least as important the intervention itself. In the jargon of theorists of the human environment, our perception of encounters with reality is no longer simply reducible to one unique space and time. As a result of perpetual exposure to multiple spatialisation of ideas, the image that matters to the mind takes the form of a temporal superposition of virtual traces of such influences. It retains at best only linguistic allegiance to what it stood for in baroque allegories.

The huge demand for timely custom-made narratives rapidly displacing argument and factuality came to be satisfied by what turned out to be an inexhaustible source of 'material' for such an enterprise: the expanding records of all that has been written down, photographed, painted, planned and built, advertised and sold, including the outpourings of social media. The internet and its enabling apps and media dot coms made this resource not only readily accessible but also modifiable without much chance of an effective punishment! Yet among much waste and misappropriation there were also many by now notoriously well-known and demonstrably original developments leading to a forward looking genealogical sequence of interventions that take advantage of deep understanding of causal forces bringing about unheard of flexibility of application of new materials and tools, e.g. exquisite structures and materials of Missoni garments, $3 \mathrm{~d}$ printing of anything from sculptures to super-strong hatches for state of the art military hardware, inventions like the 'humble' bar code and composite materials for packaging crisps as well as the I-phone of Mr Job and Apple fame and energy saving car brakes!

\section{Whither Materia Poetica?}

What is the fate of materia poetica of today, until recently an indispensable tool not only for poets and physicists but for keeping humans sane, away from life in a bubble?

Qui facit per alium, facit per se; he who wants to express one thing by means of another always does it through himself! The old saying perhaps still applies but, more often than not, that "himself" may be several times removed from the old himself. Just as the action space of today is invariably several times removed from the level of causal forces. In the course of the last few decades, making even a simple concept 'narratable' amidst the debris of collapsed modernist consensus has become increasingly more difficult to accomplish. Such are the conditions that bring today's manner of constructing 'story telling' to something akin to baroque allegory. But now it is not just about choosing a suitable narrative but also to supply its addressees with a 'crypt', something good enough to fill the void created by the loss of collective consensuality that made allegory such an effective tool in the past! This crypt must be tailored to fit both the place and the time at which the story is to be activated - only soon to be updated as conditions change. What is more, in the digitally-enhanced, quasi-schizophrenic and place-less realm of narration materiality is something 'virtual'. Indeed, even some renown thinkers have recently classed work on e.g. software coding and internet messaging as 'non-material'!

To make people fully aware of the process of contextualization of ideas in its various stages is further complicated by the character of ontic processes as they develop at the level of complexity brought about by recent advances in techno-science under the neo-liberal imposed division of labour and wealth. Whereas for Descartes what something is happens to be constituted by its "extension", in the regime dominated by the social media, knowledge systems, and robots, the functional expression of what something is becomes better accounted for by saying what the object or system in question is doing or is treated as doing, i.e. how it is engaged in the process of material exchanges at the site of action. This dynamic ontology approach has tacitly taken over everything from making manuals to organisation of work practices. In brief, communicative action simply concentrates on the relevant subset of parameters associated with the desired function at the site of action instead of giving a full description of what the device or system is capable of, e.g. what a computer 'is' for an accountant is reduced to how it does accounts. It means that onto-epistemic constitution of object's identity now depends on the place and time of its function, i.e. on its 'journey', just as the journey is constituted by the object-event. It is at the vortices where the contextualization in social structures and projection of object-ness on the process 
belonging to a particular function meet that the magic of materia poetica peculiar to the post-mechanical, 'digital' age comes into its own. It enters the social in addition to, but often hybridised with all those encounters of the mind with matter that have fascinated humans for centuries, poets and physicists alike.

When we eventually lift our eyes from the screen, make a cup of coffee or go to buy bread, materiality of life is again unproblematic. It is another matter when we ask how materiality translates into ways of organising knowing and being. It is of essence to what is proposed here that only by engaging both the function of the mind and that of the body's in the process of material exchange constituting any human activity is it possible to establish and keep renewing creative and forward looking separation between for-himself and for-other. Until quite recently, our encounters with the world of things and humans were informed by what were thought to be universal laws of nature and society. They gave us the means to appreciate the order, regularity and structures of finitudes constitutive of our lives. Now our thoughts move in the opposite direction. Instead of drawing directionality of thought from speculative doctrines, acquisition of quantitative empirical methods and tools makes it possible radically to alter the level of our accomplishments in making and modelling these finitudes whether it is in physical and life sciences or in arts and finance - and cast them as it were for posterity into genealogical sequences organized according to taxonomy of the level of complexity based on the independent parameters constituting patterns of matter and processes of material exchanges at large. The factual content of textbook histories structured by successive speculative schemes each claiming universal validity will have gradually acquired unambiguous form and recordability in such genealogies; in fact much of what is being published, made and sold, patented etc. is already on the way - be it right now still in a rather disorderly manner - to just such a future, including works of arts and humanities! It is this turn in our development that promises to give the much needed onto-epistemic meaning and directionality to the newly created action space for seeking and making new patterns of matter and social systems. And, significantly, this is the space for providing, for the first time, conditions for independent, categorical separability of empirically demonstrable novelty from fraud, imitation, and trivia of all kind, not by labelling one good and another bad but by establishing by transparent independent means their differences. That way it is also possible to ensure that critical social feedback mechanisms are in place so as to structure this development in the interest of human-ness in which the ultimate measure of value is individual human independence and social emancipation as the only guarantee of social stability and justice. It is such engagements with object-ness in living places that are instrumental in un-concealing at least to some degree the "real existent" hidden under layers of meta-modern 'allegories'.

\section{7. "Neo-Baroque" Allegories and Corporeality in Literary Narratives of the Post-Mechanical Age}

The best of fine arts and literature have always captured, at the level of perception and observational tools of their own, 'onto-poetic' moments of the material condition of humans. Theirs is the privilege to be first in sensing - well before rendering understandable - novel object-events of human encounters with emergent interfaces of corporeality. In doing so, they render visible the creative, emancipatory potential of direct sensory encounters with the order of things. Such moves are of necessity embedded in and compelled to coexist with remains of disparate cultural heritage. For in the pre-modern age meaning was to be found in codifying texts like Homer's Odyssey or the Bible, i.e. in the Given. Then Galilean "measure and quantify" left the moderns to find meaning out of their Reason. But it soon transpired that such meanings can only be contingent. They reflect the status of images of rapidly evolving levels of complexity and their normative impact on social impropriation of products of independent thought. Not surprisingly, the rise of science and technology has been accompanied by an increase in the influence of scientific models of the world, and their varied projection on the social in the audio-visual and literary narratives, and taken up as a vehicle for highlighting the enigma of human desire for self-expression.

In his enchanting monograph, Daniel Tiffany shows how models of, for example, the solar system, rainbow, radiation, automatons, astro-catastrophic singularities, and, importantly, the formula like sequences of thought moves that accompany any such models, found their way into the literature and arts as an inexhaustible source of poetic inspiration. Yet this ascend contains a paradox. It would appear that repeated re-contextualization of such models increasingly more popular in constructing and sustaining narratives grants them a new life of their own; it bursts forth in fresh analogies and legitimizes its fictional genealogy as 'the real'. This detachment of models of corporeality from their original representational roles and constitutive mechanisms strips them of the closure characteristic of their mathematical-scientific origin and makes them open to manipulative re-and-de-composition. Models of heavenly bodies, automatons, radiation, big bang etc. re-appear - to borrow the unforgettable phrase of Alfred Jarry's Ubu - as "pata-physics" though they still look like the 'real stuff'.

Already in the $17^{\text {th }}$ century some literati endeavoured to share inspirational narratives with what they thought were the ways of a scientist. So much so that Samuel Johnson is reported to have complained about the so-called 
metaphysical poets who he thought were particularly guilty of this crime. In his view, such inclinations might turn poetry into a branch of physics. The ancient belief linking the origin of light, sound, and consequently human communication to heavenly bodies retained its hold on human imagination. Indeed, since Pythagoras people believed that what we see and hear is the mysterious power of matter or atoms originating in cosmic bodies such as the sun and the stars. Ether - the mysterious, invisible, yet ever present 'gas' - was thought to be a "condition of intelligibility of physics". This matter enters us and with it the unique divine spirit. In notorious stories of E. T. A. Hoffmann this trend is taken one step further, e.g. in his Olympia; in Yeats' Sailing to Byzantium the soul of the old man is an artefact. From tales of Golem to Yeats' bird-automaton, literary narratives invoked human obsession with desire to master the mystery of matter and its 'living', to compete with God - now even by making intelligent machinic systems! Needless to add, without such 'existential' role of materia poetica, status of much of the modern fiction would probably be quite low.

What is it that takes the place of traditional models of corporeality and their supply of materia poetica? For several decades we have been 'plugged' into the flow of newly organised material finitudes - whether in the shape of silicon microstructures and genes or globalised networks of manufacture and communication systems into what shattered the relative closure of modernist canon into an open and rapidly changing experiential space. Already Umberto Eco argued that the hold of cultural legacies on our experience of life has been fatally weakened, indeed rendered obsolete by the advent of man-made materials and systems, by what he called the age of simulacra. An update today could boast with examples from film, literature, and theatre of recent manifestations of collapse of 'linearised - made - predictable' models of the world, of nature and society, and of their emergent replacements, e.g. in Tom Stoppard's masterpieces Arcadia and The Hard Thing. In fine arts, design, and architecture we have moved from oil canvases and columns of stone to e.g. The Weather Project of Olafur Eliasson's installation of 2004 in the Tate Modern and the roof over the courtyard of the British Museum in London. It is a process much documented at disparate levels of discourse! Clearly Hannah Arendt's 'self' is becoming 'narratable' through a manifold of novel flows of material exchanges of energy peculiar to the post-mechanical age. The object mediating between the text - really layers of medialised messaging - and the self plays a crucial role in granting reality to actuality of the self. This mediator object-event is an archetypal doll, the toy of all those brilliant minds celebrated in Tiffany's book, the bearer of the burden of irredeemable loss in our emergent finitudes of the Absolute. It is now connected wirelessly to the causal drivers of the world stuck deep under the layers of allegoric narrations like a remote, disabled pseudo-algorithmic puppeteer sporadically dazzled by the rays of old wonderings about radiant bodies in the sky, about materia poetica of snow flakes, automatons, dolls, and marionettes making up the anecdotal richness of our inheritance.

In order to manage the intellectual space in which meaningful narratives can be made, writers of very different background and orientation deliberately constructed and sustained literary narratives by invoking the legitimating power of 'allegories' and their judicious embodiments. It rests in sequences of thought that want to be believable by the hint of almost scholarly sounding detail. Not in the actual substance of objects or factuality figuring in the argument that often turn out to be ambiguous and trivial, but in the process that carries forward the whole edifice. In the eighteen-page opening passage of Eco's Foucault's Pendulum the reader is taken from one artefact to another in the famous Sala Lavoisier in the Conservatoire. This session sets the tone and methodology of the book. In these descriptions the lines of as if data points are themselves relevant only as a vehicle, a legitimating frame in motion erected there to make one believe in the depth and truth of being, as an onto-epistemic variable for self-identification of his hero. He is a young man called Casaubon waiting for a midnight sign from the Pendulum. Of course, his name is no less than a deeply cryptic reference - and there are many more maintaining the momentum of the narrative as one might expect from Eco the professional historian - here to the scholarly bishop Edward Casaubon of George Eliot's Middlemarch fame! As he waits, he is thinking, about 'physics', about life and things at large. "Was it worth the trouble of going through the Encyclopaedia, and the Revolution to be able to state that merely curving a mirror's surface can plunge a man into an imagined world? ... Or is the message really that we should look at everything in a different way, including...the instruments that supposedly celebrate the birth of physics and enlightened chemistry?" The brilliant literary move of shifting what would belong to a physics laboratory to a museum, from Casey's "Place" to the Exhibition Hall is enough to make Casaubon's moment with the Pendulum and all it stands for in our predicament 'narratable': to abolish the closure of Newton's laws and its thing-as-an-instrument! The reader is to be left alone with the bare process of observation and sequences of thought associated with, but never fully in view of the variables in question such as the symmetry and pathway of reflection, the surface topology of the mirror, the formula for light propagation and reflection that constitute it! Just like his baroque fellow-allegorists, Eco finds it impossible, even undesirable to live up to the regime of direct argument. His narrative consists of superimposed layers each readable either as yet another stream of the detective plot or, for those who can reach it, 
with its crypt pointing to this or that zig zag movement of the age lost in complexifications and simulacra. Every time Eco came with a new book, he raised the stakes. Though people able to read crypts in his Prague Cemetery must be a select group indeed!

Another masterly example offering an original way of contextualisation of the current material condition of humans can be found in Max Sebald's collection of short stories called Vertigo. He makes his method explicit: “...tiny details (of structured material reality) imperceptible to us decide everything”. Just as in Eco's brilliant and superbly informed use of allegory, they often enter the text as pseudo-factual 'information' - such as that "50 000 horses and men were killed at the battle of Waterloo". Though without any 'evidence', it still looks as if the story was if not based on at least 'in view of' empirical facts. The battlefield of Waterloo, and its 'facts', turn up again as if out of nowhere in The Rings of Saturn. It is a methodological tool, his 'nonlinear' equation of textual motion that, just like in Eco's texts though in its own distinct form, when iterated often enough suddenly produces an unexpected turn, a new metaphor. There are also inserted in his texts strings of names of persons and objects of archaeological importance, photos (intentionally of poor quality) of landscapes, décor, tickets, buildings, dresses, schematic drawings, and brand marks. This is a signature of the bottom up, archaeological genealogical method of building up 'existence' out of layers of loosely connected objects. They give the text a feel of authentic empirical grounding and serve as an ontic parameter. Just as Umberto Eco in his Foucault Pendulum, and even more so Walter Benjamin in his Arcades Project, there are carefully selected details of measurable physical properties such as material (mineral) composition, colour and sound, light (crystalline) reflection, and specific acts of process or performance. Then sensory experience enters the mind as if the image of objects before it were 'distorted' by a superposition of traces of records deposited there as a result of previous encounters with or participation in object-events; it is as it were an allegory of the quantum-probabilistic representation of observation that consists of "virtual admixtures" into what might be a zero order approximation to what happens of other possible states of matter. At a different mode of complexity, e.g. in philosophy of Gill Deleuze, we might talk in this context about "folds" of time and pseudo-vectors of motion.

More recently, this trend reached new heights. In the last novel of much praised Hilary Mantel [35], the figure of Henry VIII's right hand manipulator Thomas Cromwell resembles so much 'Dom' Cummings - the current chief of staff of the British Prime Minister - that it would not escape the attention of even a hurried reviewer. Unlike the generous use of cultural contextualisation of well-placed historical detail of Foucault's Pendulum, in Mantel's masterly stark text places and movements of people are reduced to shorthand of craftily dry 'physicality' of bodies, dates, and geography. Indeed, portrayal of e.g. Cromwell's attitude to women or accounts of his master and mistress' sexuality are almost contemporary, not to mention the manipulative turns worthy of manners of a top level hedge fund manager. Is it not an allegory of the neo-liberal society? For there is really no history in this history; the trilogy reads like skilfully arranged sequences of transactions, of movements of property, bribes, bodies and corpses, of brutal levelling of 'facts' about maintenance of the state as well as lust for genitals and power!

A very different master piece of allegorism - though one also highly praised be it in rather different quarters - is The Capital of Robert Menasse. Here we are in present day Brussels and its headquarters of the European Commission hosting the vast administrative apparatus of the European Union representing 27 member states, languages, histories, and customs. It is Eco transported well into the $21^{\text {st }}$ century and brought to new heights of the raging 'baroque reason'; the book begins and is carefully punctuated with appearances of a pig wandering through the city as if at the invitation of its masters. Alas! The vigorous instantaneous attention given to this tourist nevertheless remains at the level of sound and print with none of the actors feeling competent to act.

Among the number of allegoric layers of the plot full of subtle irony and humour figures prominently the flagship of one of the Commission's DGs, the "Jubilee Project". It is driven entirely by personal self-interest in the battle of apparatchiks for power. There we periodically touch the philosophical plane of the work, at least those who can read its crypts which crop up every time the stakes are raised. Already early in the book a newly appointed upstart proposes that there be a celebration of the anniversary of the foundation of the Commission. Not quite a punchy excuse for action that will cost money. But it has to be something of 'European' importance that could be 'celebrated' within a year of two; that appears to be the range of institutional attention these days. Under the veil of a routine detective story, with its usual side-lines moving the plot from one layer of the narrative to another, a word is dropped here and there about the inspiration for and the driver of this project. Cryptic references to another Jubilee celebration in the making stand out - to a project of no lesser a hero of literary history, and of the heady days of Vienna Circle, Robert Musil's Ulrich, The Man without Qualities [37]! And we are told that Musil's happens to be the favourite novel of Head of the Commission himself, often 
debated with his close associates. There is much to be discussed for we know that, and how, Ulrich in the end abandoned his project, career, and mistress - to devote himself to loving his sister.

Just as with movements of the pig, the book is punctuated with references, at points of ascending order of quasi-schizophrenic, directionless social entanglements, to the speech given at the launch of the Commission. It proposed that this organisation's chief function be to make sure that arbitrary will can never be allowed to impose itself upon fellow Europeans. It of course referred to the Camps and events that led to them, at that time still relatively fresh in the European mind. As any allegorist proper, he makes this visible to his crypt readers without any patronising analysis. A layered cocktail of facts and fiction is designed systematically to project upon the story telling the pata-physics of neo-liberal institutions and their separation from the productive forces that ultimately decide how the present Establishment must 'catch up' with events. As a witness to all those happenings and bearer of its 'crypt', each layer of the narrative is richly embodied in its particular class of materiality, from the furniture of Camps to chairs screwed to the floor of an upmarket retirement home of one of the key survivor-actors!

The title chosen by a highly reputed reviewer for his report about this book wittingly sums up: "The Union without Qualities". Else, it is of course a pleasant detective story.

\section{Summary and Conclusions}

When we lift our eyes from the screen and make a cup of coffee, materiality of life and perhaps even its poetica are unproblematic. It is another matter when we ask how materiality translates into ways of knowing and being. Until recently, our encounters with the world have been informed by what were thought to be universal laws of nature and society. They gave us the means to appreciate regularity and structure of finitudes constitutive of our lives. Today novelties of form and organisation are caught in runaway complexifications of life and their actuality remains hidden from view. Often they are by many orders of magnitude removed from the scale of powers of human senses and further obscured by pseudo-structures of surface appearances staring at us everywhere; worse, their materiality and organisation are transported into the void of the virtual, and stripped of directionality of reason and valuation. The thinker deprived of a stable source of meaning has always resorted to allegory, i.e. by speaking of one thing under the guise of another. This is what happened after the collapse of the authority of Summa Theologica and particularly in the aftermath of religious wars that followed.

The ambiguity and openness to re-interpretation characteristic of allegory was exploited by both the baronial power of the establishment as well as by those who looked for a way to challenge it without falling victim to persecution. Though the message was hidden behind the veil of allegory, in European Risorgimentos the 'crypt' was owned one way or another by those for whom it was intended. The $20^{\text {st }}$ century brand of fragmentation and contingency of being and doing, and the misery of rising inequality and insecurity brought the baroque art of allegory to new heights of 'digital enhancement'. Whatever possible social benefit may have potentially remained in saying by other means what cannot be said directly is doomed to failure because of the absence of a commonly shared crypt. Today narrative patterns depend on ephemeral meanings manipulated in the media. They invariably contain insatiable will to meaning and salvation without ever providing it.

However, it also transpires that new technologies and the methods of modelling they have fostered have matured in this century and offer means to novel engagements with object-ness potentially instrumental in un-concealing the "real existent" hidden under layers of meta-modern allegories. Acquisition of quantitative empirical methods and tools makes it possible radically to alter the level of our accomplishments and cast them as it were for posterity into genealogical sequences organized according to taxonomy of the level of complexity based on independent parameters constituting patterns of matter and processes of material exchanges at large. Textbook and current histories until recently structured by successive speculative schemes will have gradually acquired an unambiguous form and recordability in such genealogies. Already much of what is being published, made and sold, patented etc. is on the way - be it still in a rather disorderly manner - to just such a future, including arts and humanities! It is this turn in our development that promises to open an elbow room for creativity free of doctrinaire impositions and to provide for independent, categorical separation of empirically demonstrable novelty from fraud, imitation, and trivia of all kind! Not by labelling one good and another bad but by establishing and organising by transparent independent means their differences. That way it may also be possible to maintain critical social feedback mechanisms in which the ultimate measure of value is individual human independence and social emancipation as the only guarantee of social stability and justice.

Recent initiatives show that no amount of top down instruction, good will or revolutionary fervour are a substitute for bottom up, personal ownership of knowledge and work. The ontic power of personal encounters with material objects is needed today more than ever as the ultimate source of identity constitutive means of 
legitimation and redemption of life-sustaining narratives. It is to instil a timely attitude, habitual practices with fitting competences, and self-confidence in applying them. They will be best achieved by grounding them in personal ownership of experiential situations the way an archaeologist uncovers layer by layer a buried city. She finds strings connecting pieces across layer boundaries previously thought to be autonomous when recognised as belonging to fraternal material structures. Fortified with bottom up grasp of what is before it, the mind can develop capacity for discrimination in confrontation with medialised impositions designed to reduce the 'problem' to one of the pre-packaged solutions floating in the cyberspace. The model of curriculum and competence development - grounded in object based, project driven, personal ownership of knowing, and amplifying the tutor-learner component at the expense of top down 'talk and chalk' - recently developed to take higher education into the digital age may be instrumental in delivering such objectives and prove to be particularly relevant in post-Covid 19 conditions. It is also a means to fostering narrative novelty with a view to ensuring that every individual can effectively engage with materiality of their presence and build upon its appreciation and on any inspiration it can offer, at the pace and level of accomplishment matching their personal ability and circumstances.

\section{References}

Also Morris, I. (2013). The Measure of Civilisation. Princeton, Princeton University Press.

Arendt, H. (1958). The Human Condition. Chicago, Chicago University Press.

Benjamin, W. (1998). The Origin of German Tragic Drama. London, Verso.

Benjamin, W. (1999). The Arcades Project. Harvard University Press.

Buci-Glucksmann, C. (1994). Baroque Reason. London, Sage Publ.

Casey, E. (1998). The Fate of Place. Berkeley, Univ. of Calif. Press.

Cavarero, A. (2000). Relating Narratives. London; Routledge.

Danto, A. C. (1997). After the End of Art. Princeton, Princeton University Press.

Deleuze, G. (1993). The Folds. Minneapolis, University of Minnesota Press.

Deleuze, G., \& Guattari, F. (1994). What is Philosophy. New York, Columbia University Press.

Eco, U. (1989). Foucault's Pendulum, London, Secker \& Warburg. Transl. William Weaver.

Eco, U. (1992). Introduction. In O. Calabrese (Ed.), Neo-Baroque: a sign of the times. Princeton, Princeton Univ. Press.

Foster, H. (2011). The Art-Architecture Complex. London, Verso.

Foster, H. (2015). Bad New Days Art, Criticism, Emergency. London, Verso.

Fuchs, C. (2014). Digital Labour and Karl Marx. London: Routledge.

Gombrich, E. H. (1969). Search of Cultural History. Oxford: Oxford Univ. Pres.

Jaros, M. (2004). Materia Poetica: Models of Corporeality and Pata-Physics in Literary Narratives. Presented at the Conference on Science and Literature, Leeds University, UK. Retrieved from https://newcastle.academia.edu/MilanJaros

Jaros, M. (2005). Materia Poetica: Models of Corporeality and Onto-Poetic Pata-Physics of the Post-Mechanical Age. Technoetic Arts, 3(1), 3-12.

Jaros, M. (2007). Towards re-definition of space-ness in the post-mechanical age: Methodological notes. Landscape and Urban Planning, 83, 84-89.

Jaros, M. (2009). Pedagogy for knowledge recognition and acquisition: knowing and being at the close of the mechanical age. The Curriculum Journal, 20, 191-208.

Jaros, M. (2014). Leadership and Competence Development in Higher Education: Reconstituting the Human-Machine Interfaces in the Space of Digital Systems. American Journal of Educational Research, 2(10), 898-905.

Jaros, M. (2014). Leadership and Methodology Challenges in Higher Education: Developing Competence in the Digital Age. Global Education Review, 2, 64-89.

Jaros, M. (2018). Reconciling Human Systems with Emergent Knowledge: Work and Value Today. Journal of Advances in Social Science and Humanities, 4(12), 453-7. 
Jaros, M. (2019). The Episteme of Meta-Modernity: Order, Value, and Citizenship in the Space of Digital Finitudes. The International Journal of Social Science and Humanities Inventions, 6(4), 5391-5399.

Jaros, M. (2019). Transmissivity of Measure and Value in Human Systems. Journal of Advances in Social Science and Humanities, 5(8), 939-948.

Jarry, A. (1997). Ubu. Transl. McLeish K. London: Nick Hern Books.

Mantel, H. (2020). The Wolf Hall. London, Fourth Estate.

Menasse, R. (2019). The Kapital. New York, Liveright Publishing Corporation.

Miller, A. (2014). Colliding Worlds. London, W.W. Norton.

Mirowski, P. (2013). Never Let a Serious Crisis Go to Waste. London, Verso.

Morris, I. (2010). Why the West Rules-For Now. New York: Farrah, Strauss \& Giroux.

Musil, R. (1955). The Man without Qualities. London, Penguin.

Nowotny, H. (2016). The Cunning of Uncertainty. Cambridge, Polity.

O’Toole, F. (2019). The Union without Qualities (pp. 14-16). The New Your Review of Books LXVI.

Osborne, P. (2018). The Postconceptual Condition. London, Verso.

Sebald, W. B. (2000). Vertigo. London, Harvill. Transl. Michael Hulse.

Smith, B. C. (1996). On the Origin of Objects. Cambridge, MIT Press.

Spiller, N. (2008). Digital Architecture Now. London: Thames and Hudson.

Steyer, H. (2017). Duty Free Art. London, Verso.

Tiffany, D. (2000). Toy Medium. Berkeley, Univ. of Calif. Press.

Transl, W. E., \& Kaiser, E. (2017). For background conceptualizations see e.g. Sigmund K. Exact Thinking in Demented Times. New York, Basic Books.

Wu, T. Y., \& Ohmura, T. (1962). Quantum Theory of Scattering. London, Prentice-Hall.

\section{Copyrights}

Copyright for this article is retained by the author(s), with first publication rights granted to the journal.

This is an open-access article distributed under the terms and conditions of the Creative Commons Attribution license (http://creativecommons.org/licenses/by/4.0/). 